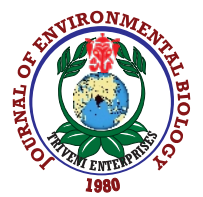

\title{
Performance of potato variety Kufri Megha under different irrigation scheduling and date of planting at North Eastern Indian mid hills
}

\author{
M. Gogoi*, Lala I.P. Ray, Sanjay-Swami, K. Kant and N.K. Meena \\ College of Post Graduate Studies in Agricultural Sciences, Central Agricultural University, Umiam (Barapani)-793 103, India. \\ *Corresponding Author Email : meghna.gogoi91@gmail.com
}

\section{Abstract}

Aim: To assess the performance of winter potato (Solanum tuberosum L.) variety Kufri Megha, under real time based irrigation scheduling, i.e., ratio of depth of irrigation water to cumulative pan evaporation in mid hills of Meghalaya during winter season of 2016-17.

Methodology: A field trial with three different irrigation scheduling as main-treatments, viz., IW: CPE- $0.75\left(\mathrm{I}_{1}\right)$, IW: CPE- $1.00\left(\mathrm{I}_{2}\right)$ and IW: CPE- $1.25\left(\mathrm{I}_{3}\right)$, four different dates of planting, viz., ${ }^{\text {st }}$ November $\left(D_{1}\right), 11^{\text {th }}$ November $\left(D_{2}\right), 21^{\text {st }}$ November $\left(D_{3}\right)$ and $1^{\text {st }}$ December $\left(D_{4}\right)$ was laid out and replicated thrice. Irrigation was provided with a micro sprinkler irrigation system and was laid out in split plot design.

Results: The plants planted on $11^{\text {th }}$ November and irrigation scheduled at IW: CPE-1.25 recorded higher values for plant height $(\mathrm{cm})$, number of branches per plant, leaf area index, dry matter accumulation per plant, net assimilation ratio, crop growth rate, relative growth rate, tuber yield $\left(\mathrm{tha}^{-1}\right)$, haulm yield ( $t$ ha $\left.{ }^{-1}\right)$, harvest index $(\%)$, water use efficiency and benefit cost ratio over other treatments.

Interpretation: It can be recommended that by following climatological approach of cumulative pan evaporation for irrigation scheduling in potato using micro sprinkler method of irrigation, the crop water requirement could be met during lean period to avoid moisture stress in plants coupled with planting at the right climatic conditions.

Key words: Benefit cost ratio, Irrigataion scheduling, Winter potato

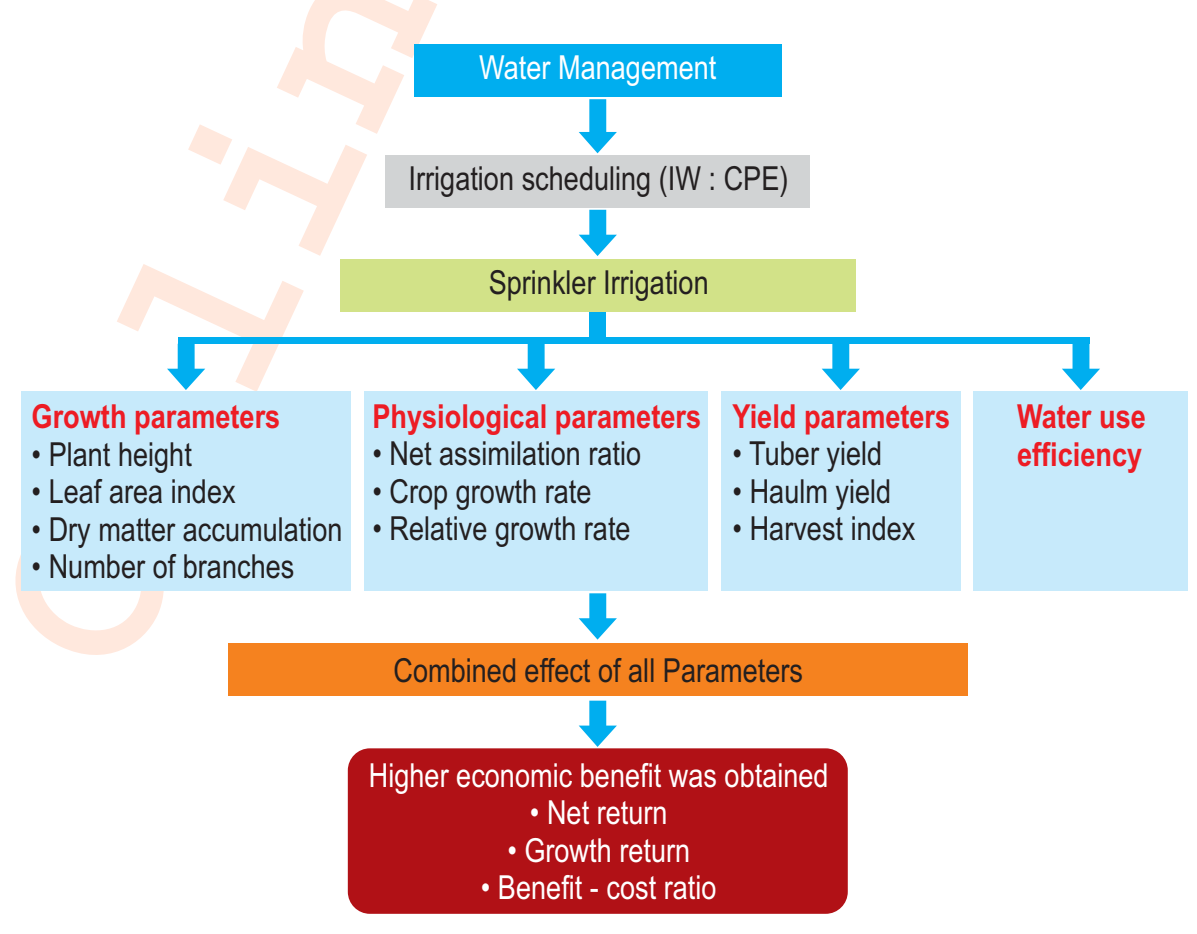

How to cite : Gogoi, M., Lala I.P. Ray, Sanjay-Swami, K. Kant and N.K. Meena: Performance of potato variety Kufri Megha under different irrigation scheduling and date of planting at North Eastern Indian mid hills. J. Environ. Biol., 41, 1605-1610 (2020). 


\section{Introduction}

In the North-Eastern Region of India, especially the hilly tracts, potato is an important crop and is grown under rainfed conditions (Sah et al., 2011). It fulfils all the criteria for a healthy food and offers a great potential for decreasing global food crisis. Potato is commonly known as the "king of vegetables" owing to its production in more than 100 countries (Kot et al., 2020). Around the world, potatoes are highly consumed food (Jagadeesan et al., 2020). Almost $10 \%$ of India's total potato area is covered by the $\mathrm{NEH}$ region. As a percentage of the net cropped area in the country, the area occupied under potato in this region is about four times of the national average (Kumar et al., 2008). Potato productivity $\left(8.16\right.$ tha $\left.^{-1}\right)$ of this region is very low as the agriculture production system followed is mostly rainfed, mono-cropped and subsistence level (Roy Burman et al., 2007). Within the NorthEast region, the maximum area and production under potato crop is in the state of Assam, whereas Tripura has the highest productivity. The lowest productivity around 4.16 tha $^{-1}$ is observed in Sikkim (Yadav and Srivastava, 2015). One of the major constraints of low productivity of potato in Meghalaya may be attributed to the lack of optimum water availability during the growing season. The crop grown in the hilly terrains are mostly rainfed. The total rainfall received is adequate or more than the crop water requirement, but the rain is not equally distributed, hence, the crop faces drought or flood like conditions during its growing period. So, during winter season proper irrigation is needed to meet the crop water requirement for obtaining higher crop yield. Proper irrigation scheduling can arrest crop water stress, improve yield, and ensure efficient use of energy and production cost and it is environment friendly. Potato is grown mostly as a temperate crop during rabi season, but it can also be grown successfully under sub-tropical areas. It grows best under short day condition coupled with abundant sunshine and cool nights. Environmental changes (sunshine, rainfall, temperature, relative humidity, wind) associated with different sowing dates has modifying effect on the growth and development of potato. Planting at appropriate time is very critical for yield optimization as delay in planting date can lead to a linear decrease in tuber yields. Owing to favourable temperature conditions, potato is planted under a wide range of dates in Meghalaya from September to first week of January. Thus, a specific window of planting of potato is ascertained to the farmers of this region then it would help to grow healthy plants and increase potato production. Thus, it is of great interest to study the effects that various planting dates have on the crop yield of potato.

\section{Materials and Methods}

An agronomical field experiment was executed during winter 2016-17 at the farms of the College of Postgraduate Studies, Barapani (CAU, Imphal), to study the yielding capacity of potato variety Kufri Megha under three different irrigation scheduling IW:CPE-0.75(I1), IW:CPE-1.00(I2), IW:CPE-1.25(I3) with four different dates of planting $1^{\text {st }}$ November (D1), $11^{\text {th }}$ November (D2), $21^{\text {st }}$ November (D3) and $1^{\text {st }}$ December (D4).

The experimental site is situated at $25^{\circ} 40^{\prime} \mathrm{N}$ latitude and 91018' E longitude at an altitude of $950 \mathrm{~m}$ above mean sea level. The texture of soil is sandy clay loam type with $1.36 \mathrm{mg} \mathrm{m}^{-3}$ bulk density. The $\mathrm{pH}$ soil was acidic in nature with $\mathrm{pH} 4.4$, rich in organic carbon (1.60\%), $\mathrm{K}_{2} \mathrm{O}\left(275 \mathrm{~kg} \mathrm{ha}^{-1}\right)$ and medium in available nitrogen $\left(229.97 \mathrm{~kg} \mathrm{ha}^{-1}\right)$ and $\mathrm{P}_{2} \mathrm{O}_{5}\left(14.35 \mathrm{~kg} \mathrm{ha}^{-1}\right)$. The potato variety used has a good yield potential with a medium duration (100-120 days). Recommended doses of fertilizers viz., N, P and K = 100: 80: $60 \mathrm{~kg} \mathrm{ha}^{-1}$ along with farm yard manure @ $15 \mathrm{t}$ ha $^{-1}$ was applied two weeks before sowing of potato. Full doses of $\mathrm{P}_{2} \mathrm{O}_{5}$ and $\mathrm{K}_{2} \mathrm{O}$ were applied along with $50 \%$ of $\mathrm{N}$ at the time of sowing. The remaining $50 \%$ of nitrogen was applied as top dressing at tuber initiation stage. Urea, single super phosphate and murate of potash were applied. Based on soil water depletion, scheduling irrigation water was applied with $0.5 \mathrm{hp}$ electric pump set by volumetric basis and the total quantum of water applied was worked out. Data obtained from various studies during investigation were statistically analysed by analysis of variance for split plot design. The difference between treatment means was tested for their statistical significance with appropriate critical difference $(C D)$ value at $5 \%$ level of probability.

\section{Results and Discussion}

The plant growth attributes viz., plant height and dry matter accumulation; leaf area index and number of branches per plant recorded at 15 days interval are presented in Table 1.

Plant height was found to have an increasing trend with the advancement of crop growth and maximum value was attained at harvest stage. Among different irrigation treatments, significant result was found in plant height at 45 and 60 DAS, where irrigation at IW: CPE: 1.25 recorded maximum plant height. Previous studies have reported that at different stages of growth limited soil water availability decreases plant growth (Yuan et al., 2003). Plant height showed significance difference with different dates of planting, at different crop growth stages viz., 45 and 60 DAS because cells are extremely active and efficient during early growth period. However, after 75, 90 and 105 DAS plant height difference was found non-significant. It occurred due to starting of senescence period in potato crop, where further increase in plant height comes to a plateau.

Among different irrigation schedules, the highest dry matter accumulation per plant recorded significant result from 60 upto 105 DAS. Dry matter accumulation per plant was higher in case of irrigation scheduled at IW: CPE-1.25 (46.84 g) due to optimum availability of soil moisture and no period of water stress conditions (Apotikar et al., 2016). Higher leaf area index registered under $11^{\text {th }}$ November planted crop was highly responsible for increase in dry matter production because higher leaf area development gave large photosynthesis potential sites. 
Table 1 : Effect of irrigation scheduling and date of sowing on plant growth attributes (plant height and dry matter accumulation)

\begin{tabular}{|c|c|c|c|c|c|c|c|c|c|c|c|c|}
\hline \multirow[t]{2}{*}{ Parameters } & \multicolumn{6}{|c|}{ Plant height (cm) } & \multicolumn{6}{|c|}{ Dry matter accumulation (g per plant) } \\
\hline & $30 \mathrm{DAS}$ & 45 DAS & 60 DAS & 75DAS & 90 DAS & 105DAS & 30 DAS & 45 DAS & 60DAS & 75DAS & $90 \mathrm{DAS}$ & 105 DAS \\
\hline \multicolumn{13}{|c|}{ Main-plot irrigation scheduling (I) } \\
\hline IW:CPE-0.75 (I $\left.I_{1}\right)$ & 8.48 & 9.86 & 13.40 & 23.28 & 27.61 & 28.24 & 3.53 & 4.37 & 5.99 & 15.50 & 27.48 & 29.27 \\
\hline IW:CPE-1.00 ( $\left.\mathrm{I}_{2}\right)$ & 8.63 & 11.75 & 15.58 & 24.30 & 28.88 & 29.51 & 3.82 & 4.87 & 6.78 & 20.35 & 35.45 & 38.18 \\
\hline IW:CPE-1.25 $\left(\mathrm{I}_{3}\right)$ & 8.17 & 14.75 & 18.32 & 25.57 & 29.99 & 30.61 & 3.86 & 5.25 & 8.14 & 24.41 & 42.16 & 46.84 \\
\hline S.E.(m) \pm & 0.43 & 0.60 & 0.61 & 0.0 .61 & 0.75 & 0.87 & 0.11 & 0.22 & 0.26 & 0.60 & 1.50 & 1.60 \\
\hline C.D. $(p=0.05)$ & NS & 2.37 & 2.39 & NS & NS & NS & NS & NS & 1.00 & 2.35 & 5.87 & 6.23 \\
\hline \multicolumn{13}{|c|}{ Sub-plot date of planting (D) } \\
\hline $1^{\text {st }}$ November $\left(D_{1}\right)$ & 8.58 & 12.56 & 16.47 & 25.47 & 29.47 & 30.14 & 3.88 & 5.20 & 7.61 & 22.81 & 39.61 & 42.77 \\
\hline $11^{\text {th }}$ November $\left(D_{2}\right)$ & 8.60 & 13.64 & 18.18 & 26.47 & 30.36 & 32.02 & 3.93 & 5.47 & 8.57 & 27.38 & 47.07 & 52.11 \\
\hline $21^{\mathrm{st}}$ November $\left(\mathrm{D}_{3}\right)$ & 8.48 & 11.94 & 14.62 & 23.60 & 28.15 & 28.32 & 3.85 & 4.66 & 6.16 & 17.23 & 30.91 & 33.03 \\
\hline $1^{\text {st December }}\left(\mathrm{D}_{4}\right)$ & 8.06 & 10.33 & 13.78 & 21.99 & 27.32 & 27.32 & 3.28 & 3.99 & 5.54 & 12.93 & 22.53 & 24.47 \\
\hline S.E. $(m) \pm$ & 0.61 & 0.53 & 1.07 & 1.92 & 3.46 & 3.43 & 0.19 & 0.20 & 0.21 & 1.00 & 1.20 & 1.39 \\
\hline$C . D(p=0.05)$ & NS & 1.13 & 1.25 & NS & NS & NS & NS & 0.59 & 0.63 & 2.95 & 3.55 & 4.12 \\
\hline \multirow[t]{2}{*}{ Parameters } & \multicolumn{6}{|c|}{ Leaf area index } & \multicolumn{6}{|c|}{ Number of branch } \\
\hline & $30 \mathrm{DAS}$ & 45DAS & $60 \mathrm{DAS}$ & 75DAS & $90 \mathrm{DAS}$ & 105DAS & 30 DAS & 45 DAS & $60 \mathrm{DAS}$ & 75DAS & 90 DAS & 105 DAS \\
\hline \multicolumn{13}{|c|}{ Main-plot irrigation scheduling (l) } \\
\hline IW:CPE-0.75 (I $\left.I_{1}\right)$ & 0.09 & 0.61 & 1.00 & 1.52 & 1.90 & 1.98 & 1.17 & 1.49 & 1.57 & 1.55 & 1.83 & 1.83 \\
\hline IW:CPE-1.00 ( $\left.\mathrm{I}_{2}\right)$ & 0.12 & 0.69 & 1.17 & 1.73 & 2.11 & 2.15 & 1.25 & 1.48 & 1.71 & 1.90 & 1.95 & 1.95 \\
\hline IW:CPE-1.25 $\left(\mathrm{I}_{3}\right)$ & 0.13 & 0.79 & 1.47 & 2.03 & 2.45 & 2.45 & 1.28 & 1.71 & 1.93 & 1.97 & 2.12 & 2.13 \\
\hline S.E. $(m) \pm$ & 0.01 & 0.03 & 0.05 & 0.09 & 0.05 & 0.06 & 0.04 & 0.05 & 0.05 & 0.07 & 0.06 & 0.6 \\
\hline C.D. $(p=0.05)$ & NS & 0.11 & 0.18 & 0.34 & 0.19 & 0.22 & NS & 0.18 & 0.18 & 0.27 & NS & NS \\
\hline \multicolumn{13}{|c|}{ Sub-plot date of planting (D) } \\
\hline $1^{\text {st }}$ November $\left(D_{1}\right)$ & 0.18 & 0.85 & 1.26 & 1.81 & 2.16 & 2.16 & 1.09 & 1.56 & 1.74 & 1.82 & 2.04 & 2.04 \\
\hline $11^{\text {th }}$ November $\left(D_{2}\right)$ & 0.12 & 0.98 & 1.45 & 2.03 & 2.49 & 2.65 & 1.36 & 1.73 & 2.01 & 2.16 & 2.20 & 2.20 \\
\hline $21^{\text {st }}$ November $\left(D_{3}\right)$ & 0.11 & 0.55 & 1.12 & 1.62 & 2.02 & 2.02 & 1.31 & 1.57 & 1.66 & 1.62 & 1.84 & 1.84 \\
\hline $1^{\text {st December }}\left(D_{4}\right)$ & 0.11 & 0.41 & 1.02 & 1.58 & 1.95 & 1.95 & 1.18 & 1.39 & 1.52 & 1.62 & 1.78 & 1.78 \\
\hline S.E. $(m) \pm$ & 0.01 & 0.03 & 0.10 & 0.05 & 0.16 & 0.17 & 0.05 & 0.07 & 0.06 & 0.09 & 0.07 & 0.08 \\
\hline C.D $(p=0.05)$ & NS & 0.09 & 0.30 & NS & NS & 0.52 & 0.13 & 0.21 & 0.18 & 0.27 & 0.22 & 0.23 \\
\hline
\end{tabular}

Leaf area index increased very noticeably upto 75 DAS, between 75 to 105 DAS, the difference was very nominal. Lahlou et al. (2003) reported the influence of water stress on aerial parts of potato. The decrease in the size of leaf is the first morphological manifestation of water stress (Jefferies and MacKerron, 1987). The reduction in leaf size leads to lesser light interception, ultimately leading to reduced dry matter accumulation in tubers (Deblonde et al., 1999). Among different dates of planting, leaf area index was significantly affected and decreased with delay in sowing. At 45 and 60 DAS, when significant results were observed, the plants attained a maximum leaf area index values of around 1.45, followed by 1.26, 1.12 and 1.02 for second, first, third and fourth dates of sowing, respectively.

A close-knit relation existed between the luxuriant growth of plant parts and amount of available water. Irrigation scheduled at regular IW: CPE-1.25 $\left(\mathrm{I}_{3}\right)$ provided water to plants more frequently than IW: CPE-1.00 $\left(\mathrm{I}_{2}\right)$ and IW: CPE-0.75 $\left(\mathrm{I}_{1}\right)$ which increased plant growth resulting in tall plants with more numbers of branches. Similar kind of results were also reported by Yuan et al. (2003). Tubers planted on $11^{\text {th }}$ November yielded more number of branches per plant compared to other treatments. This positive growth is attributed to favourable climatic conditions received during growth period.

The net assimilation rate, crop growth rate and relative growth rate are presented in Table 2. Net assimilation rate revealed a declining trend as the age of crop advanced in both the case of irrigation scheduling and date of planting. In irrigation scheduling, treatments all observations had non-significant results, except during 60-75 DAS. IW: CPE- 1.25 was at par with IW: CPE- 1.00 but both recorded significantly higher NAR over IW: CPE- 0.75. The planting date performance was nonsignificant throughout the growing period, but during 60-75 DAS, 
$D_{2}$ had significantly highest net assimilation rate over treatments $D_{3}$ and $D_{4}$ however, it was statistically at par with $D_{1}$. At the end of the growth period, net assimilation rate became low due to increase in temperature, falling off of leaves and low level of photosynthesis Fonseka et al. (1996).

The crop growth rate of potato showed an increasing trend from 30-45 DAS upto 75-90 DAS, after which the values of CGR went low in both the cases of irrigation scheduling and planting date treatments. In different irrigation scheduling, crop growth rate was found significantly higher in $\mathrm{I}_{3}$ over $\mathrm{I}_{2}$ and $\mathrm{I}_{1}$ during 45-60, 60-75 and 75-90 DAS. During 75-90 DAS, the CGR recorded low values because of falling of old leaves (Borego et al., 2000). The planting date performance had significant effect on CGR at all the crop growth stages due to suitability of climatic conditions for growth and development during $D_{2}$ date of planting in the regions, along with $D_{1}$, which also performed at par with $D_{2}$.

Relative growth rate increased at a regular trend and reached a maximum value during 60-75 DAS and gradually recorded a decreasing trend as the crop advanced to its maturity stage. Relative growth rate showed non-significant results with irrigations treatments during the crop period, however, the growth was increased up to 60-75 DAS in case of both irrigation scheduling and planting date treatments. The decrease in relative growth rate may be attributed to decrease in net assimilation rate and possibly due to aging effects. Rao and Mitra (1988) reported a decrease in plant relative growth rate due to decrease in its net assimilation rate. In sub plot treatments, during 60-75 DAS significantly highest relative growth rate was observed from $D_{2}$, over $D_{3}$ and $D_{4}$ but was at par with $D_{1}$ due to prevalence of suitable environmental conditions. Similar results were also reported by Begum etal. (2015).
The haulm yield, tuber yield, harvest index and water use efficiency are presented in Table 3.

In main-plot treatment, haulm yield recorded significantly high in both $\mathrm{I}_{3}\left(5.31\right.$ tha $\left.^{-1}\right)$ and $\mathrm{I}_{2}\left(4.61\right.$ tha $\left.^{-1}\right)$ over $\mathrm{I}_{1}\left(3.38\right.$ t ha $\left.^{-1}\right)$ was due to luxuriant growth of crop (stems and leaves) no water stress condition in $I_{3}$ followed by $I_{2}$ and unlike $I_{1}$. Similar observations were also validated by Amanulla et al. (2010). Even with moderate water deficit, it recorded a reduced above-ground biomass (lerna and Mauromicale, 2006). However, tubers planted at different date of planting showed non-significant results on haulm yield.

Both the irrigation scheduling treatments, $\mathrm{I}_{2}$ and $\mathrm{I}_{3}$ had significantly higher tuber yield over $l_{1}$ because of less depletion of available soil moisture from the plant root zone. In order to produce high yield and high tuber quality, high water availability is required with minimal soil moisture content variation (Alva et al., 2012; Tyagi et al., 2013). In planting date treatments $D_{2}$ and $D_{1}$ showed significant higher yield of tuber over $D_{4}$. This happened because of high leaf area duration and leaf area index at early crop growth stages. This early establishment in the growth increases the photosynthetic capacity and the amount of photosynthates produced in the crop, ultimately leading to higher tuber yield production Patel et al. (2010). As plants were exposed to lower climatic temperature range in early period along with a short photo period, it resulted in an increase in yield loss with delay in planting.

Harvest index is used to assess the proficiency of division of dry matter by a plant harvest index in both irrigation scheduling and date of planting was found to have non-significant results due to late un-seasonal rainfall encouraged the vegetative growth in all treatments at later stage of plant growth. Van Loon (1981) also suggested similar observations of vigorous top growth when

Table 2: Effect of irrigation scheduling and date of sowing on plant growth rate

\begin{tabular}{|c|c|c|c|c|c|c|c|c|c|c|c|c|c|c|c|}
\hline \multirow[t]{3}{*}{ Parameters } & \multicolumn{5}{|c|}{ Net assimilation rate $\left(\mathrm{g} \mathrm{m}^{-2} \mathrm{~d}^{-1}\right)$} & \multicolumn{5}{|c|}{ Crop growth rate $\left(\mathrm{g} \mathrm{m}^{-2} \mathrm{~d}^{-1}\right)$} & \multicolumn{5}{|c|}{ Relative growth rate $\left(\mathrm{mg} \mathrm{g}^{-1} \mathrm{~d}^{-1}\right)$} \\
\hline & $30-45$ & $45-60$ & $60-75$ & $75-90$ & $90-105$ & $30-45$ & $45-60$ & $60-75$ & $75-90$ & $90-105$ & $30-45$ & $45-60$ & $60-75$ & $75-90$ & $90-105$ \\
\hline & DAS & DAS & DAS & DAS & DAS & DAS & DAS & DAS & DAS & DAS & DAS & DAS & DAS & DAS & DAS \\
\hline \multicolumn{16}{|c|}{ Main-plot irrigation scheduling (I) } \\
\hline $\mathrm{I}_{1}$ & 0.86 & 0.92 & 2.17 & 2.01 & 0.26 & 0.56 & 1.08 & 6.34 & 7.98 & 1.18 & 6.07 & 8.85 & 26.81 & 16.32 & 1.75 \\
\hline $\mathrm{I}_{2}$ & 0.87 & 0.95 & 2.71 & 2.89 & 0.41 & 0.70 & 1.27 & 9.05 & 10.07 & 1.76 & 6.98 & 9.29 & 30.84 & 15.99 & 2.46 \\
\hline $\mathrm{I}_{3}$ & 1.00 & 1.09 & 2.77 & 2.39 & 0.54 & 0.93 & 1.92 & 10.85 & 11.83 & 3.11 & 8.58 & 12.85 & 31.09 & 16.36 & 2.74 \\
\hline S.E. $(m) \pm$ & 0.17 & 0.16 & 0.07 & 0.23 & 0.11 & 0.10 & 0.13 & 0.41 & 0.80 & 0.30 & 1.03 & 1.06 & 1.09 & 0.96 & 0.43 \\
\hline C.D. $(p=0.05)$ & NS & NS & 0.26 & NS & NS & NS & 0.52 & 1.62 & NS & 1.16 & NS & NS & NS & NS & NS \\
\hline \multicolumn{16}{|c|}{ Sub-plot date of planting (D) } \\
\hline$D_{1}$ & 0.94 & 1.01 & 2.97 & 2.48 & 0.47 & 0.88 & 1.61 & 10.13 & 11.19 & 2.09 & 8.42 & 11.16 & 31.47 & 15.98 & 2.20 \\
\hline$D_{2}$ & 0.97 & 1.04 & 3.27 & 2.69 & 0.57 & 1.03 & 2.06 & 12.54 & 13.13 & 3.28 & 9.19 & 13.04 & 33.58 & 15.94 & 2.78 \\
\hline$D_{3}$ & 0.84 & 0.92 & 2.31 & 2.29 & 0.29 & 0.54 & 1.00 & 7.38 & 9.12 & 1.41 & 5.47 & 8.03 & 29.03 & 16.99 & 2.06 \\
\hline$D_{4}$ & 0.88 & 0.98 & 1.65 & 1.65 & 0.28 & 0.48 & 1.03 & 4.92 & 6.40 & 1.29 & 5.76 & 9.09 & 24.24 & 15.98 & 2.24 \\
\hline S.E.(m) \pm & 0.20 & 0.22 & 0.25 & 0.37 & 0.14 & 0.15 & 0.16 & 0.70 & 1.25 & 0.46 & 1.48 & 1.24 & 1.88 & 1.96 & 0.68 \\
\hline C. $D(p=0.05)$ & NS & NS & 0.75 & NS & NS & 0.44 & 0.48 & 2.09 & 3.71 & 1.38 & NS & 3.69 & 5.59 & NS & NS \\
\hline
\end{tabular}


plants are re-watered after a period of high temperature and drought.

Water use efficiency recorded non-significant results for main as well as sub-plot treatment. However, $\mathrm{I}_{3}$ registered higher WUE $\left(51.77 \mathrm{~kg} \mathrm{ha}^{-1} \mathrm{~mm}^{-1}\right)$ over $\mathrm{l}_{1}\left(50.35 \mathrm{~kg} \mathrm{ha}^{-1} \mathrm{~mm}^{-1}\right)$ and $\mathrm{I}_{2}(48.18$ $\left.\mathrm{kg} \mathrm{ha}^{-1} \mathrm{~mm}^{-1}\right)$. The results revealed that irrigation given at less depletion of available soil moisture showed an increase in the yield of tubers, water use efficiency and saved water. Bisht et al. (2012) also reported similar results. $D_{2}$ recorded highest WUE over $D_{1}, D_{3}$ and $D_{4}$. Reduction in water use efficiency under late sown conditions has also been reported in mustard (Awasthi et al., 2007; Patel et al., 2008). Optimum planting date facilitated drought escape in plants by matching the crop growth cycle to the amount and pattern of rainfall which ultimately minimized the chances of exposure of the crop to water deficit at drought susceptible stages. Hence, increasing the yield and water use efficiency of early-sown crops.
Gross revenue values decreased from optimum irrigation to least irrigated treatments. Significant result was found on gross return, net return and $\mathrm{BC}$ ratio in irrigation scheduling treatments, where both $I_{3}$ and $I_{2}$ were significantly higher over $I_{1}$ (Table 4 ). The maximum gross return, net return and benefit cost ratio recorded were ₹ $2,04,872$, ₹ 1,13,346 and 2.24, respectively, in $I_{3}$. Similar such results were also reported by Sadawarti et al. (2013) and Srivastava et al. (2016). In case of gross return, net return and benifit cost ratio in planting date treatments showed significant result of $D_{2}$ over $D_{3}$ and $D_{4}$, but was statistically at par with $D_{1}$. The highest net return, gross return and benefit cost ratio in case of $\mathrm{I}_{3}$ followed by $\mathrm{I}_{2}$ was because of the highest yield in the treatments, similarly, highest return in $D_{2}$ followed by $D_{1}$, had same reasons.

Based on the data, it may be concluded that irrigation scheduled at IW: CPE ratio of $1.25\left(\mathrm{I}_{3}\right)$ with micro sprinkler irrigation system is an advanced and suitable irrigation system as

Table 3 : Effect of irrigation scheduling and date of sowing on plant yield, yield attributes and water use efficiency

\begin{tabular}{|c|c|c|c|c|}
\hline Parameters & Haulm yield ( $\left.\mathrm{t} \mathrm{ha}^{-1}\right)$ & Tuber yield ( $\mathrm{tha}^{-1}$ ) & Harvest index (\%) & $\begin{array}{l}\text { Field water use efficiency } \\
\left(\mathrm{kg} \mathrm{ha}^{-1} \mathrm{~mm}^{-1}\right)\end{array}$ \\
\hline \multicolumn{5}{|c|}{ Main-plot irrigation scheduling (I) } \\
\hline IW:CPE-0.75 (I $\left.I_{1}\right)$ & 3.38 & 10.91 & 75.12 & 50.35 \\
\hline IW:CPE-1.00 ( $\left.\mathrm{I}_{2}\right)$ & 4.61 & 13.38 & 75.57 & 48.18 \\
\hline IW:CPE-1.25 $\left(\mathrm{I}_{3}\right)$ & 5.31 & 17.07 & 76.66 & 51.77 \\
\hline S.E. $(m) \pm$ & 0.13 & 0.55 & 2.30 & 1.93 \\
\hline C.D. $(p=0.05)$ & 0.51 & 2.17 & NS & NS \\
\hline \multicolumn{5}{|c|}{ Sub-plot date of planting (D) } \\
\hline $1^{\text {st }}$ November $\left(D_{1}\right)$ & 4.58 & 14.19 & 75.96 & 50.37 \\
\hline $11^{\text {th }}$ November $\left(D_{2}\right)$ & 4.74 & 15.30 & 76.16 & 56.09 \\
\hline $21^{\text {st }}$ November $\left(D_{3}\right)$ & 4.37 & 13.45 & 75.88 & 49.71 \\
\hline $1^{\text {st December }}\left(D_{4}\right)$ & 4.05 & 12.21 & 75.13 & 44.23 \\
\hline S.E. $(\mathrm{m}) \pm$ & 0.22 & 0.57 & 2.62 & 2.10 \\
\hline C. $D(p=0.05)$ & NS & 1.69 & NS & 6.23 \\
\hline
\end{tabular}

Table 4 : Effect of irrigation scheduling and date of sowing on benefit and cost ratio of potato cultivation

\begin{tabular}{|c|c|c|c|}
\hline \multirow[t]{2}{*}{ Treatments } & \multicolumn{3}{|c|}{ Economic analysis } \\
\hline & Gross return (₹) & Net return (₹) & Benefit : Cost ratio \\
\hline \multicolumn{4}{|c|}{ Main-plot irrigation scheduling (I) } \\
\hline IW:CPE-0.75 (l $\left.\mathrm{I}_{1}\right)$ & $1,30,924$ & 40,398 & 1.45 \\
\hline IW:CPE-1.00 (I $\left.I_{2}\right)$ & $1,60,582$ & 69,556 & 1.76 \\
\hline IW:CPE-1.25 $\left(\mathrm{I}_{3}\right)$ & $2,04,872$ & $1,13,346$ & 2.24 \\
\hline S.E. $(m) \pm$ & 6,037 & 6,037 & 0.07 \\
\hline C.D. $(p=0.05)$ & 23,696 & 23,696 & 0.26 \\
\hline \multicolumn{4}{|c|}{ Sub-plot date of planting (D) } \\
\hline $1^{\text {st }}$ November $\left(D_{1}\right)$ & $1,70,327$ & 79,300 & 1.87 \\
\hline $11^{\text {th }}$ November $\left(D_{2}\right)$ & $1,83,659$ & 92,632 & 2.02 \\
\hline $21^{\text {st }}$ November $\left(D_{3}\right)$ & $1,61,344$ & 70,318 & 1.77 \\
\hline $1^{\text {st December }}\left(D_{4}\right)$ & $1,46,508$ & 55,482 & 1.61 \\
\hline S.E. $(m) \pm$ & 6,803 & 6,803 & 0.07 \\
\hline$C . D(p=0.05)$ & 20,210 & 20,210 & 0.22 \\
\hline
\end{tabular}


it produced highest tuber yield $\left(17.07 \mathrm{t} \mathrm{ha}^{-1}\right)$, helped in saving a good amount of water and increase the water use efficiency. The analysis also demonstrated that among different dates of planting, $11^{\text {th }}$ November $\left(D_{2}\right)$, recorded to be suitable planting date for potato cultivation in hilly regions of Meghalaya during rabi season with a $B: C$ ratio of 2.24 . Thus, it can be concluded that $I_{3} D_{2}$ i.e., irrigating potato at IW: CPE ratio of 1.25 and planting on $11^{\text {th }}$ November gave the highest yields with a good economic return in hilly regions of Meghalaya.

\section{Acknowledgment}

The financial support received from the Central Agricultural University, Imphal during Master Degree Programme is acknowledged.

\section{References}

Alva, A.K., A.D. Moore and H.P. Collins: Impact of deficit irrigation on tuber yield and quality of potato cultivars. J. Crop Impr., 26, 211$227(2012)$

Amanullah, A.S.M., S.U. Talukder, A.A. Sarkar and A.S.M. Ahsanulla: Yield and water use efficiency of four potato varieties under different irrigation regimes. Bangladesh Res. Pub. J., 4, 154-264 (2010).

Apotikar, V. A., A.V. Solanke, M.G. Ghanbahadur, S.S. Mane and S.R. Dalal: Effect of sowing windows on growth functions and dry matter accumulation. Int. J. Trop. Agricul., 34, 1749-1753 (2016).

Awasthi, U.D., R.B. Singh and S.D. Dubey: Effect of sowing date and moisture conservation practice on growth and yield of Indian mustard (Brassica juncea) varieties. Indian J. Agron., 52, 151-153 (2007).

Begum, F., B.C. Kundu and M.I. Hossain: Physiological analysis of growth and yield of potato in relation to planting date. $\mathrm{J}$. BangladeshAcad. Sci., 39, 45-51 (2015).

Bisht, P., M. Raghav and V.K. Singh: Effect of different irrigation schedules on the growth and yield of drip irrigated potato. Potato J., 39, 202-204 (2012).

Borego, F.M., A. Fernandez, V. lopez, M. Murillo and A. Carvajal: Growth analysis in seven potato cultivars (Solanum tuberosum). Agronomia Mesoamerican, 11, 145-149 (2000).

Deblonde, P.M.K., A.J. Haverkort and J.F. Ledent: Responses of early and late potato cultivars to moderate drought conditions. Agronomic parameters and carbon isotope discrimination. Eur. J. Agron., 11, 91-105(1999).

Fonseka, H.D., K. Asanuma, A. Kustani, A. K. Ghosh and K. Ueda: Growth and yield of potato cultivars in spring sowing. Japan J. Crop Sci., 65, 269-276 (1996).

lerna, A. and G. Mauromicale: Physiological and growth response to moderate water deficit of off-season potatoes in a Mediterranean environment. Agric. WaterManage., 82, 193-209 (2006).
Jagadeesan, S., I. Govindaraju and N. Mazumder: An insight into the ultrastructural and physiochemical characterization of potato starch:Areview. Amer. J. Potato Res., 97, 464-476 (2020).

Jefferies, R.A. and D.K.L. MacKerron: Aspects of the physiological basis of cultivar differences in yield of potato under droughted and irrigated conditions. Potato Res., 30, 201-217 (1987).

Kumar, S., U. Sah, C. Deka, L.K. Baishya, N.K. Pandey, P.H. Singh and S.K. Pandey: Farmer participatory research for design and delivery of situation specific potato production technology in Meghalaya. Potato J., 35, 78-84 (2008).

Kot, A.M., K. Pobiega, K. Piwowarek, M. Kieliszek, S. Błażejak, M. Gniewosz and E. Lipińska: Biotechnological methods of management and utilization of potato industry waste - A review. Potato Res., 63, 431-447 (2020).

Lahlou, O., S. Ouattar and J.F. Ledent: The effect of drought and cultivar on growth parameters, yield and yield components of potato. Agronomie., 23, 257-268 (2003).

Patel, D.B., N.A. Patel and V.M. Modi: Influence of different dates of potato planting on stem necrosis disease. Int. J. Plant Prot., 3, 404$405(2010)$.

Patel, I.C., B.S. Patel, M.M. Patel, A.G. Patel and S.B.S. Tikka: Effect of irrigation schedule, dates of sowing and genotypes on yield, water use efficiency, water expense efficiency and water extraction pattern of cowpea. J. Food Legumes, 21, 175-177 (2008).

Rao, L.J. and B.N. Mitra: Growth and yield of peanut as influenced by degree of shedding. J.Agron. crop Sci., 160, 260-265 (1988).

Roy Burman, R., M. Kumar and K.M. Nagaraj: Organic potato production- practices and extension strategy. In: Advances in organic farming Technology in India (Eds.: G.C. Munda et al.) pp. 271-279 (2007).

Sadawarti, M.J., S.P. Singh, V. Kumar and S.S. Lal: Effect of mulching and irrigation scheduling on potato cultivar kufri chipsona-1 in central India. Potato J., 40, 65-71 (2013).

Sah, U., S.K. Dubey and J.P. Sharma: Potato marketing in north east region of India: A diagnostic study. J. Comm. Mobiliz. Sust. Deve., 6, 194-201 (2011).

Srivastava, A.K., S.K. Yadav, L.C. Diegdoh, R. Rai and T.K. Bag: Effect of varieties and planting dates on productivity of potato (Solanum tuberosum L.) in north eastern hill region. Env. Eco., 34, 141-145 (2016).

Tyagi, V.K., O.V.S. Thenua, D. Kumar and N. Singh: Productivity, water use and economics of potato (Solanum tuberosum L.) + French bean (Phaseolus vulgaris L.) intercropping system as affected by water management. Ann. Agric. Res., 34, 138-143 (2013).

Van Loon, C.D.: The effect of water stress on potato growth, development and yield. Am. Potato J., 58, 51-69 (1981).

Yadav, S.K. and A.K. Srivastava: A review on agronomical aspects of potato production in north-eastern region of India. Int. J. Appl. Pure Sci.Agric. (IJAPSA), 1, 26-34 (2015).

Yuan, B.Z., S. Nishiyama and Y. Kang: Effects of different irrigation regimes on the growth and yield of drip-irrigated potato. Agric. Water Manage., 63, 153-167 (2003). 